\title{
The Interrelationship between Insulin-Like Growth Factor 1, Apolipoprotein E \&4, Lifestyle Factors, and the Aging Body and Brain
}

\author{
S.A. Galle ${ }^{1,2, *}$, I.K. Geraedts ${ }^{1, *}$, J.B. Deijen ${ }^{1,3}$, M.V. Milders ${ }^{1}$, M.L. Drent ${ }^{1,4}$
}

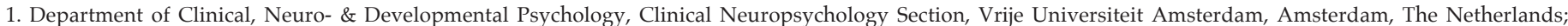

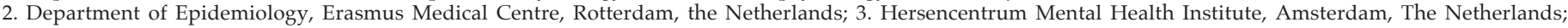

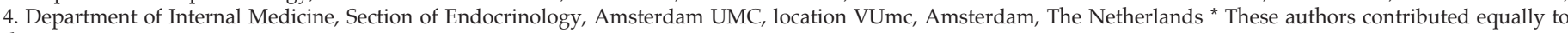
this work

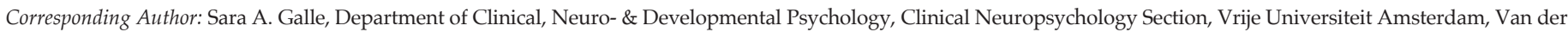
Boechorststraat 7-9, 1081 BT Amsterdam, The Netherlands, T: 0031205988769, E-mail: s.a.galle@vu.nl

\begin{abstract}
Aging is associated with a decrease in body and brain function and with a decline in insulin-like growth factor 1 levels. The observed associations between alterations in insulin-like growth factor 1 levels and cognitive functioning and Mild Cognitive Impairment suggest that altered insulin-like growth factor 1 signaling may accompany Alzheimer's disease or is involved in the pathogenesis of the disease. Recent animal research has suggested a possible association between insulin-like growth factor 1 levels and the Apolipoprotein E $\varepsilon 4$ allele, a genetic predisposition to Alzheimer's disease. It is therefore hypothesized that a reduction in insulin-like growth factor 1 signaling may moderate the vulnerability to Alzheimer's disease of human Apolipoprotein E $\varepsilon 4$ carriers. We address the impact of age-related decline of insulin-like growth factor 1 levels on physical and brain function in healthy aging and Alzheimer's disease and discuss the links between insulin-like growth factor 1 and the Apolipoprotein E \&4 polymorphism. Furthermore, we discuss lifestyle interventions that may increase insulin-like growth factor 1 serum levels, including physical activity and adherence to a protein rich diet and the possible benefits to the physical fitness and cognitive functioning of the aging population.
\end{abstract}

Key words: Insulin-like growth factor, Alzheimer's disease, ApoE-c4 allele, physical activity, diet, aging.

\section{Introduction}

I $t$ is well known that the process of aging is associated with physical and mental changes. In the body, normal aging is primarily associated with a decrease in muscle mass and strength. In the brain, normal aging is mainly characterized by metabolic changes in the prefrontal cortex and associated with a decrease in brain size and synaptic plasticity (1). These changes in body and brain lead to alterations in physical, as well as cognitive functioning in elderly people, such as increased frailty and decreased cognitive performance (1, 2).

When age-related cognitive decline becomes qualitatively severe and progresses rapidly, it is likely to progress into a clinical diagnosis of dementia. The most common form of dementia is Alzheimer's disease (AD). While there are some medications that decelerate the neuropathological progression of $\mathrm{AD}$ or offer some symptomatic relief, there is no cure available. In the absence of a cure for $\mathrm{AD}$, research has focused on the most common risk factors and preventive strategies. Important non-modifiable risk factors for $\mathrm{AD}$ that have been investigated include age and genetics. Potentially modifiable factors are risk factors that are associated with lifestyle like socioeconomic factors, diet, cerebrovascular disease, and physical inactivity (3).

In the development of preventive strategies, it is important to understand the interplay between

neurobiological and lifestyle factors. One important factor that is both influenced by lifestyle factors like physical activity and diet $(4,5)$ and plays a role in the maintenance of physical fitness (6) and cognitive functioning (7) is insulin-like growth factor 1 (IGF-1). This review will discuss the impact of age-related decline of IGF-1 levels on physical and cognitive functioning in healthy aging and AD. In addition, we discuss the possible link between IGF-1 and ApoE- $\varepsilon 4$. Furthermore, we explore how lifestyle interventions focusing on physical activity and diet may be useful to improve physical fitness and cognitive functioning by increasing IGF-1 serum levels.

Insulin-like growth factor 1 is a peptide growth hormone, with a structure similar to insulin, encoded by the IGF-1 gene located on chromosome 12. As part of the growth hormone $(\mathrm{GH}) /$ IGF-1 axis, IGF-1 plays an essential role in growth of the body and development of the brain. IGF-1 is mainly produced in the liver, stimulated by GH, which is secreted from the anterior pituitary gland. IGF-1 can also be produced in local peripheral tissues such as muscle and bone tissue when GH binds to its Growth Hormone Receptor (GHR) (8). As IGF-1 is GH dependent and, unlike GH, circulating IGF-1 levels do not fluctuate widely over time, IGF-1 is a more reliable measure and appropriate marker for $\mathrm{GH}$ status (9). Therefore, this review focuses on neurobiological processes and lifestyle factors related to IGF-1. 


\section{IGF-1 and the aging body}

Throughout the body, IGF-1 regulates the development and function of cells. It promotes cell growth and contributes to cell proliferation, stress resistance and survival in many cell types (10). IGF-1 can bind with high affinity to the IGF-1 receptor (IGF-1R), but also to the insulin receptor (11) as its structure is closely related to insulin. The IGF-1R is expressed in many distinct tissues in the body. For this reason IGF-1 can have different effects, such as the promotion of neuronal survival in the central nervous system and the facilitation of peripheral muscle regeneration (12). Because of the essential role of IGF-1 in muscle growth and the involvement of IGF-1 in many mechanisms and functions of the body, IGF-1 is an important factor for embryonic and childhood growth (13) and anabolic processes in adults (14).

Aging is associated with a decline in IGF-1 (10). The progressive decline has been termed the 'somatopause', which may be caused by potential alterations of the hypothalamic regulation of GH secretion, in particular an age-dependent decrease in endogenous hypothalamic GHRH output, contributing to the age-associated GH and IGF-1 decline (15). Moreover, low physical fitness and higher adiposity in older individuals also contribute to the decreased GH secretion and associated IGF-1 decline (16). Low levels of IGF-1 are associated with decreased skeletal muscle mass and function (17). Studies have shown that IGF-1 serum levels are positively associated with muscular strength and walking speed and are negatively associated with self-reported difficulty in mobility tasks (18). Systemic infusion of GH over 8 hours led to increased GH and IGF-1 concentration levels and increased muscle protein synthesis in eight healthy young adults aged 18 to 24 years (19). In addition, Rudman et al. (20) demonstrated increased lean body mass, average vertebral bone density, IGF-1 levels, and decreased body fat following GH administration over 6 months in nine healthy adults that were not observed in 12 untreated healthy adult men. Mauras et al. (14) used recombinant human IGF-1 (rhIGF-1) treatment to increase IGF-1 plasma levels in 10 patients with Laron's syndrome, characterized by GH receptor deficiency, and showed that increased IGF-1 plasma levels were associated with increased lean body mass and decreased fat mass. Furthermore, Dik et al. (21) demonstrated that higher IGF-1 serum levels were associated with fewer functional limitations (e.g. difficulties with climbing stairs, cutting toenails, use of public transport) in 1318 healthy participants aged 65 to 88 years. This association suggests that reduced IGF-1 levels in older people might make them more prone to these functional limitations.

The influence of IGF-1 on bone development has been demonstrated using mouse models. Bikle et al. (22) found a $24 \%$ decrease in cortical bone size and reduced femoral lengths, but increased connectivity and trabecular bone density, in IGF 1 deficient (Igf-1 -/-) mice. In addition, a study by Courtland et al. (23) used inducible liver IGF-1 deficient mice to deplete IGF-1 serum levels at varying times in mice development and demonstrated that depletion of serum IGF-1 levels at four weeks in male mice resulted in reduced trabecular and cortical bone acquisition by 16 weeks. Depletion of serum IGF-1 levels in mice of eight weeks resulted in decreased cortical bone properties at 32 weeks, whereas depletion of IGF-1 serum levels after peak bone acquisition at 16 weeks did not lead to detrimental effects on bone.

Finkenstedt et al. (24) demonstrated that 12 months of recombinant human GH (rhGH) treatment of 18 adult male and female patients, with adult onset $\mathrm{GH}$ deficiency, and an average age of 44 years, resulted in increased markers of bone formation and resorption and elevated IGF-1 levels compared to the untreated group. Following rhGH treatment for 12 months, markers for bone turnover, including bone formation and resorption, increased relative to baseline in those patients who were treated with rhGH. In addition, after 12 months, IGF-1 was significantly increased in all patients treated with rhGH, and bone mineral density in the lumbar and proximal spine was increased in this group, particularly in patients with low bone mass. Furthermore, one month of recombinant human GH administration in 10 healthy older men, with an average age of 68 years, led to improved balance and stair climb time as well as increased muscle IGF-1 gene expression (25). Ohlsson et al. (26) also showed that low IGF-1 serum levels in elderly men were associated with increased risk of bone fractures (e.g. hip, spine), which are partly caused by falls and are a clear marker of physical frailty. Muscle weakness, functional limitations, and age are substantial contributors to the risk of falls in elderly and these factors are all associated with a decrease in IGF-1. Hence, the age-related decrease in IGF-1 may play an important role in the increased incidence of falls in elderly.

\section{IGF-1 and the aging brain}

IGF-1 produced by the liver has the ability to cross the blood-brain barrier and can subsequently bind to IGF-1 receptors expressed throughout the brain. High densities of IGF-1 receptors are observed in various brain areas including the amygdala, thalamic nuclei, hippocampus, superficial and deep cortical layers, olfactory bulb, cerebellum, cerebral cortex, caudate nucleus, frontal cortex and the putamen (27). In addition, IGF-1 is also produced in brain tissues and can thereby act locally via paracrine or autocrine mechanisms. IGF-1 plays an important role in neuronal growth, the maintenance of synapses and the protection of neurons in the brain (28). Furthermore, IGF-1 has been found to enhance and maintain myelination, essential for the propagation of neuronal impulses, in the central nervous system (CNS) as well as in the peripheral nervous system.

Age-related decline of IGF-1 levels is associated 
with altered brain function. Sonntag et al. (29) showed age-related decreases in IGF-1 receptor density in hippocampal and cortical regions in rats. The authors found that IGF-1 mRNA levels were reduced in the cerebellum in older rats, compared to younger ones. This decline was associated with an increase in cell death (30). As IGF-1 is involved in maintaining myelination in the CNS, age-related IGF-1 decline may be associated with the breakdown of myelination which in turn may have a negative impact on cognition in humans (31). This agerelated breakdown of myelin can lead to decreased signal transmission speed in neurons, essential for integration of information between highly distributed neural networks that underlie higher cognitive functions, such as executive processing (32).

\section{IGF-1, cognition and MCI}

Evidence thus far has supported the idea that IGF-1 plays an essential role in cognition. In healthy men and women, IGF-1 serum levels have been shown to be positively related to working memory (33), selective attention, executive function (34), verbal fluency and performance on the Mini-Mental State Examination (MMSE) (35). A recent study by Maass et al. (36) demonstrated that an increase in IGF-1 serum levels was positively associated with hippocampal volume and verbal memory recall in a population of healthy elderly. In childhood-onset GH deficient men GH substitution improved both mood and memory. These improvements were maintained during the 10 year follow-up period (37).

With respect to pathological cognitive aging, IGF-1 levels have been found to be reduced in people with MCI compared to cognitively healthy people. MCI is associated with reduced performance in various cognitive domains, including attention, executive function, processing speed, visuospatial skill and memory. Doi et al. (38) conducted a population survey in 3355 participants with an average age of 71.4 years and found that people with MCI showed decreased IGF-1 serum levels compared to cognitively healthy people. Furthermore, Calvo et al. (39) showed a positive association between IGF-1 serum levels and cognitive performance, mainly in the domains of learning and memory, in elderly people with MCI, suggesting IGF-1 may be neuroprotective in elderly people susceptible to AD. This notion is supported by the finding that the cognitive impairments in AD may be partly related to reduced IGF-1 serum levels (40).

\section{IGF-1 and AD}

At a neurobiological level AD is characterized by several neurotoxic effects caused by senile plaques (SPs) and neurofibrillary tangles (NFTs) that lead to synaptic dysfunction, neuronal cell death and cerebral atrophy, mainly in the hippocampus and temporal and parietal lobes. The main elements of SPs are beta-amyloid $(A \beta)$ aggregates. These $A \beta$ aggregates form plaques outside neurons that intervene with communication between neurons at synapses and contribute to neuronal cell death. NFTs, on the other hand, are primarily composed of hyperphosphorylated tau protein. Deviant abnormal tau proteins inside neurons (tau tangles) block the transports of essential molecules, such as nutrients in the neuron, thereby contributing to cell death. The abundance of NFTs is positively associated with the severity of $\mathrm{AD}$ (41). These brain alterations impede the transfer of information between synapses and cause a reduction in the number of synapses. The progression of the disease eventually leads to neuronal cell death causing a substantial shrinkage of the brain.

In 2007, Alvarez et al. (40) showed subnormal IGF-1 levels in adults diagnosed with AD. Additionally, Westwood et al. (42) showed that lower IGF-1 serum levels are associated with an increased risk of developing AD in older- and middle-aged people. This study also demonstrated that higher levels of IGF-1 are associated with greater brain volumes, even among cognitively healthy older and middle-aged people, suggesting a protective effect of IGF-1 against neurodegeneration. Recent evidence showed that IGF-1 resistance in the brain is increased in $\mathrm{AD}$ (43). Moloney et al. (44) demonstrated that alterations in IGF-1 receptors (IGF-1Rs) in the AD temporal cortex, including reduced expression as well as an aberrant distribution of IGF-1Rs in the neurons, contribute to impaired IGF-1R signaling in AD neurons. The deviant distribution of IGF-1Rs in neurons away from the plasma membrane suggests that IGF-1Rs are less able to respond to extracellular IGF-1 in AD, contributing to possible IGF-1R signaling resistance in neurons that degenerate (44). A decrease in IGF-1 signaling can contribute to loss of myelin function, which is thought to result in nerve fiber conduction delays found in people with AD (45). Furthermore, deficits in IGF-1 signaling have been related directly to $\mathrm{AD}$ pathology like increased accumulation of $A \beta$, phosphorylated tau, increased neuro-inflammation and apoptosis (28), suggesting that impaired IGF-1 signaling plays a role in the pathogenesis of $\mathrm{AD}$. In contrast to this idea it has also been suggested that downregulation of IGF-1 signaling is a consequence of neuropathology and alterations in IGF-1 signaling could be seen as a compensatory response to attenuate the effects of aging and neurodegeneration. This idea is supported by the assocation between suppression of IGF-1 signaling and longevity in humans (46) and the observation that low IGF-1 levels predict life expectancy in exceptionally long-lived individuals (47).

In model organisms in which IGF-1 signaling was attenuated increased lifespan and a delayed process of aging has been observed $(48,49)$. For instance, in AD mouse models the long-term suppression of IGF-1 signaling reduced neuronal loss and increased resistance 
to oxidative stress and neuro-inflammation. In line with these findings, lowerd IGF-1 serum levels in transgenic mouce models, induced by a protein restriction diet, alleviated AD pathology (50).

In human observational studies, a recent meta-analysis by Ostrowski and colleagues could not confirm the hypothesized association between serum IGF-1 and AD. From 3540 studies that analyzed the relation between IGF-1 and AD, only 10 studies provided serum IGF-1 values. These 10 studies included $850 \mathrm{AD}$ patients and 871 controls. From these studies 5 reported that AD subjects had higher IGF-1 levels, 2 reported no difference in IGF-1 levels and 3 reported lower IGF-1 levels in AD. The authors conclude that serum IGF-1 may be a personalized factor reflecting differential influence of genetic polymorphisms, age of onset or disease progression of $\mathrm{AD}$ patients (51). It is important to note that the number of included studies poses limitations to the generalizability of the results and more studies are needed to clarify the possible relationship between IGF-1 levels and AD.

\section{Potential interactions of IGF-1 and ApoE- $\varepsilon 4$ in the development of $\mathrm{AD}$}

The Apolipoprotein E gene, APOE, is the largest genetic risk factor associated with cognitive decline in late-onset AD (52). ApoE is involved in lipid transport in the central and peripheral nervous system, and brain injury repair. The three most common alleles of APOE $(\varepsilon 2, \varepsilon 3, \varepsilon 4)$ encode for the three major isoforms (ApoE- $\varepsilon 2$, ApoE- $\varepsilon 3$, ApoE- $\varepsilon 4)$ of the apolipoprotein E (ApoE), a protein that plays a central role in brain injury repair, lipid transport and metabolism. The $\varepsilon 2, \varepsilon 3$ and $\varepsilon 4$ alleles have a worldwide frequency of $8.4 \%, 77.9 \%$ and $13.7 \%$, respectively (53).

The strength of the effects of the different APOE genotypes on $\mathrm{AD}$ risk differs between ethnic groups. In the present study, we will focus on Caucasians. ApoE- $\varepsilon 3$ is often considered the neutral allele with regard to $\mathrm{AD}$ risk. Compared to the ApoE- $\varepsilon 3, \mathrm{ApoE}-\varepsilon 4$ is associated with both an increased incidence rate and an earlier onset of AD. One copy of ApoE- $\varepsilon 4$ increases the risk of developing $\mathrm{AD}$ threefold, while those who are homozygous for $\varepsilon 4$ have an approximately 13-fold increased risk (54). ApoE- $\varepsilon 4$ carriers also have an enhanced risk for developing vascular dementia and mild cognitive impairment (MCI) (55) and studies have shown that the ApoE- $\varepsilon 4$ allele is involved in the acceleration of cognitive decline (56). The accelerated cognitive decline observed in ApoE- $\varepsilon 4$ carriers could be an important clinical precursor of $\mathrm{AD}$. It has been shown that ApoE promotes the proteolytic breakdown of the $A \beta$ aggregates appearing in $\mathrm{AD}$, whereas the isoform ApoE- $\varepsilon 4$ is less effective in enhancing this breakdown (57). Moreover, Kumar et al. (58) demonstrated that neurofibrillary tangle density was increased in ApoE- $\varepsilon 4$ carriers relative to non- carriers of the allele. Hence, carrying the ApoE- $\varepsilon 4$ allele increases the vulnerability of the brain to AD pathology.

As described earlier, IGF-1 has an opposite effect to ApoE- $\varepsilon 4$ on N-methyl-D-aspartate receptor (NMDAR) signaling and $A \beta$ clearance in the brain (59). With respect to NMDAR signaling, Liu et al. (60) demonstrated that the ApoE- $\varepsilon 4$ allele enhanced an age-related decline in cognitive function in mice by decreasing NR2B subunit levels which in turn down-regulates the NMDAR pathway. Specifically, NR2B may play a role in spatial learning and long-term potentiation $(61,62)$. In contrast, IGF-1 has been found to positively affect the NMDARr pathway in rats by increasing NR2B subunits (62).

Impairments in $A \beta$ clearance are a major hallmark in early as well as late AD. People carrying the ApoE- $\varepsilon 4$ allele are more vulnerable to disturbances in $A \beta$ clearance than people not carrying this allele (63). IGF-1 supports $\mathrm{A} \beta$ clearance in the healthy brain (64).

A recent study by Keeney et al. (65) was the first to report a direct association between the three isoforms of ApoE ( $\varepsilon 2, \varepsilon 3$ and $\varepsilon 4)$ and IGF-1 by demonstrating deficient IGF-1 gene expression and reduced IGF-1 protein level in mice carrying the human ApoE- $\varepsilon 3$ and ApoE- $\varepsilon 4$, compared to mice carrying the human ApoE- $\varepsilon 2$ allele. This association indicates that the three isoforms of ApoE affect IGF-1 signaling differently, suggesting a potential mechanism that might contribute to the differences in AD risk of ApoE isoforms (65).

Moderation of the association between IGF-1 signaling and AD by APOE genotype has previously been suggested in experimental studies. Using microarray analysis of the astrocyte transcriptome, Simpson and colleagues demonstrated that as AD pathology progresses, downregulation of gene transcription in astrocytes leads to a reduction in the expression of intra-cellular insulin and IGF signaling pathways, particularly in individuals expressing the ApoE- $\varepsilon 4$ allele (66). Impaired IGF-1 signaling in human astrocytes is associated with a reduced ability to protect neurons from oxidative stress, which has been identified as an important factor in the promotion of tau and $A \beta$ pathology in $\mathrm{AD}$ (67).

Therapeutic approaches targeting insulin resistance by increasing IGF-1, insulin, or insulin sensitivity have been promising, but do suggest differential effects in people with or without genetic susceptibility to AD. More specifically, intravenous and intranasal insulin administration in patients with $\mathrm{AD}$, reduced amyloid precursor protein (APP) levels and improved memory scores only in those without the ApoE- $\varepsilon 4$ allele $(68,69)$.

Previously, our group reported tentative evidence of an interaction between the ApoE- $\varepsilon 4$ allele and IGF-1 receptor stimulating activity in an elderly cohort (59). IGF-1 receptor stimulating activity in the median and top tertiles was related with increased dementia incidence in hetero- and homozygotes of the ApoE- $\varepsilon 4$ allele, but did not show any association with dementia risk in people 
without the ApoE- $\varepsilon 4$ allele (59). The observed elevation in IGF-1 receptor stimulating activity may have marked a compensatory response to neuropathological changes associated with the ApoE- $\varepsilon 4$ genotype. Additionally, we found that the ApoE- $\varepsilon 4$ homozygotes, with a lifetime risk of Alzheimer's Disease of $80 \%$ (70), have the lowest IGF-1 levels (59). Similarly, a genome-wide association study on longevity by Deelen et al. (2001) showed that the ApoE- $\varepsilon 4$ allele was related to lower IGF-1 levels in middle-aged women. Hence, the increased risk of developing $\mathrm{AD}$ in ApoE- $\varepsilon 4$ carriers might partially be attributed to alterations in IGF-1 signaling (71).

\section{Physical activity and IGF-1}

As mentioned earlier, IGF-1 serum levels can be influenced by lifestyle factors, such as physical activity (5). Aerobic and anaerobic exercise interventions have been shown to influence IGF-1 levels. The positive effect of aerobic exercise on IGF-1 levels has been shown in a mouse study that demonstrated upregulated mRNA levels of IGF-1 in mice after 15 days of voluntary wheel running. Protein levels of IGF-1 in the dentate gyrus had also increased (72). Replication of these results in human participants was provided by several studies that showed an increase in IGF-1 serum levels following aerobic exercise in adults $(73,74)$. Likewise, a study concerning the effect of anaerobic exercise on IGF-1 serum levels reported positive effects of anaerobic training on IGF-1 levels in healthy older men (75). There is, however, still much controversy concerning the association between physical exercise and IGF-1 levels. A systematic review of experimental studies on the effect of physical activity on measures of IGF-1 and cognitive functioning in healthy elderly concluded moderate intensity aerobic training and moderate and high intensity resistance training may improve circulating IGF-1 and cognition, depending on the sex of the participant and duration of the training. However, disparities in the type of exercise, protocols and samples hinder comparison of the results and the establishment of consensus (76).

Furthermore, negative associations between IGF-1 levels and physical activity, could also be explained by favorable neuromuscular anabolic adaption, which is a normal short-term adaptive response of the body to increased physical exercise (Rarick et al., 2007). It has been thought that during episodes of active muscle building IGF-1 serum levels decrease (78), but local muscle gene expression and production of IGF-1 increase (79). Longitudinal studies on exercise interventions indicate that IGF-1 serum levels may only decline temporarily and may increase after longer duration of intensive training and are maintained when training is reduced (74). The long-term effect of physical activity on IGF-1 levels may be explained by epigenetic alterations. It is known that physical activity can contribute to changes in various physiological systems by epigenetic mechanisms (80). Physical activity may induce epigenetic modifications to the IGF-1 gene, leading to sustained increased IGF-1 levels $(6,80)$. There is evidence showing that these types of alterations can be inherited (81). In light of epigenetics and the influence of prolonged physical activity on IGF-1 levels, the current decrease in the number of physically active people, mainly in highincome countries, is alarming.

Regular engagement in physical activity could be of special importance to those with a genetic susceptibility to AD. Several studies have indicated that the negative association between regular physical activity and cognitive decline is limited to those with one or more copies of the ApoE- $\varepsilon 4$ allele. Schuit et al. registered engagement in physical activity in a group of elderly Dutch men and found that while risk of cognitive decline did not differ between active and inactive ApoE- $\varepsilon 4$ noncarriers the risk was 4 times higher in inactive ApoE- $\varepsilon 4$ carriers compared to active ApoE- $\varepsilon 4$ carriers (82). A similar finding, indicating that inactivity is especially detrimental to cognitive abilities for ApoE- $\varepsilon 4$ carriers, was reported in a longitudinal study in a Finnish cohort (83). Rovio et al. found a significant relationship between physical activity at midlife and risk of developing $\mathrm{AD}$ at a 21-year follow-up for ApoE- $\varepsilon 4$ carriers, but not for ApoE- $\varepsilon 4$ non-carriers. Additionally, Kivipelto et al. (84) demonstrated that physical inactivity increased the risk of AD mainly among ApoE- $\varepsilon 4$ carriers.

Several brain-imaging studies have reported support for these findings. Deeny et al. found that in the middleaged, sedentary ApoE- $\varepsilon 4$ carriers exhibited lower activity levels in the temporal lobe, a region known to be vulnerable to early decline in $A D$, relative to active ApoE- $\varepsilon 4$ carriers, while activity level did not distinguish between AD risk for ApoE- $\varepsilon 4$ non carriers (85). In 2012 Head et al. demonstrated that in cognitively normal older adults those who were sedentary and ApoE- $\varepsilon 4$ carriers showed more $A \beta$ deposition than active ApoE- $\varepsilon 4$ carriers, whereas this association was not present in non-carriers (86). Subsequently, Smith et al. observed that the hippocampal volume of those ApoE- $\varepsilon 4$ carriers that displayed low levels of physical activity was on average 3\% lower in comparison to non-carriers, and in comparison to ApoE- $\varepsilon 4$ carriers who displayed high levels of physical activity (87), indicating that physical inactivity may be related to brain atrophy in ApoE- $\varepsilon 4$ carriers. Together, these studies suggest that ApoE- $\varepsilon 4$ carriers may be more susceptible to the negative effects of physical inactivity, and that sedentary ApoE- $\varepsilon 4$ carriers may be at increased risk of developing AD.

In contrast, in a functional MRI study Smith et al. observed that among ApoE- $\varepsilon 4$ carriers being engaged in higher levels of physical activity was associated with greater regional brain activation during a semantic memory task in comparison to non-carriers and ApoE- $\varepsilon 4$ carriers who displayed lower levels of physical activity (88), suggesting that ApoE- $\varepsilon 4$ carriers do not suffer more 
from inactivity than any other group but do experience more benefits from physical activity.

On the other hand, studies have shown that the interaction between physical activity and cognitive decline is restricted to ApoE- $\varepsilon 4$ non-carriers. In a prospective study among older adults Podewils et al. found an inverse association between physical activity and risk of AD after a 5 year follow-up that was confined to ApoE- $\varepsilon 4$ non-carriers, indicating that benefits of exercise may be confined only to $\varepsilon 4$ noncarriers (89). A similar finding was reported after a 5 year follow-up in cognitively healthy elders (90). Fenesi et al. found a significant protective effect of physical activity regarding dementia risk in ApoE- $\varepsilon 4$ non-carriers, and no significant effect in ApoE- $\varepsilon 4$ carriers. One randomly controlled trial supported these two observational studies (91). Lautenschlager et al. studied the effect of an exercise intervention on cognitive functioning in a randomized trial in healthy older adults with subjective memory impairment. The researchers found a modest improvement in cognitive functioning in those treated with the intervention. In a post-hoc comparison, treatment response interacted with APOE genotype, as ApoE- $\varepsilon 4$ non-carriers showed a significantly larger improvement compared to both carriers and non-carriers in the control condition, while no other significant differences were found (91).

One study did not find a significant interaction effect between physical activity and cognition and ApoE- $\varepsilon 4$ carrier status (92). Luck et al. failed to find an interaction between physical activity in late life and risk of $\mathrm{AD}$ in an observational study after a 4.5-year follow-up in a group of healthy elderly aged 75 years and over. However, the authors did note that the interaction between ApoE- $\varepsilon 4$ and low physical activity for AD risk verged on the border of significance.

With regard to physical fitness, it has been found that the presence of the ApoE- $\varepsilon 4$ allele is associated with motor decline (e.g. motor performance) in older people (93) and the strength of this relationship increases with age. Further analysis showed that this association was mainly due to a greater age-related decrease in upper and lower limb muscle strength in people carrying the ApoE- $\varepsilon 4$ allele. This study showed that ApoE- $\varepsilon 4$ carriers are at greater risk of rapid motor decline relative to non-carriers, particularly later in life. Considering that limited physical activity is associated with motor decline, and physical activity is potentially protective against cognitive decline, physical activity is argued to be especially relevant to ApoE- $\varepsilon 4$ carriers $(86,93)$.

\section{Diet and IGF-1}

In addition to the effect of physical activity on IGF-1 levels, diet is an important lifestyle factor affecting IGF-1 levels. Norat et al. (4) demonstrated that protein intake was positively associated with IGF-1 serum levels. This study showed that intake of milk, calcium, magnesium, phosphorus, potassium, vitamin B6, and vitamin B2 was positively related to IGF-1 serum levels and that the intake of vegetables and beta-carotene was negatively associated with IGF-1 serum levels in women. In line with this study, a study by Allen et al. (94) demonstrated that in adult women aged 20 to 70 a plant-based (vegan) diet was related to lower IGF-1 serum levels compared to women with a meat-eating or lacto-ovo-vegetarian diet. The difference in IGF-1 serum levels between the groups was mainly explained by protein intake consisting of essential amino acids. Long-term caloric restriction for a duration of 1 and 6 years was not associated with with reduced IGF-1 serum levels in healthy middle aged men and women, if protein intake is high (95). In addition, a recent study by Fontana et al. (96) showed that 2 years of caloric restriction did not affect IGF-1 serum levels in healthy non-obese young and middleaged men and women, suggesting no sustained effects of caloric restriction on IGF-1 serum levels. Though, other studies demonstrated that short term caloric restriction for 6 days lowers IGF-1 serum levels (97), indicating that particularly short term fasting lowers IGF-1 serum levels.

\section{Exercise combined with diet and IGF-1}

Few studies have examined the influence of physical activity combined with a specific diet on IGF-1 levels. A negative caloric balance induced by physical exercise or caloric restriction, were both associated with equivalent decline in IGF-1 levels (98). Smith et al. (98) concluded that a decline in IGF-1 levels is mainly explained by an energy deficit, irrespective whether this deficit was induced by caloric restriction or physical exercise. A study by Rarick et al. (77) demonstrated a decline in IGF-1 serum levels after 7 days of increased physical activity in healthy men. However, the decrease in IGF-1 serum level was not moderated by fitness intensity, energy balance, or dietary protein intake. This study therefore challenges the concept of Smith et al. (98) and suggests that yet unknown mechanisms related to physical activity, such as enhanced energy flux, may affect IGF-1 levels independently.

\section{IGF-1 in relation to other AD risk factors}

When investigating the association between IGF-1 and Alzheimer's disease it is important to consider the limited role of epidemiological evidence in causal inference and the possible confounding influence of a myriad of factors that are related to both $\mathrm{AD}$ risk and altered IGF-1 signaling. Among these potential confounders are lifestyle factors, like alcohol and nicotine consumption (99-101), and several conditions associated with alterations in insulin or IGF-1 signaling such as type 2 diabetes, obesity, cardiovascular disease, cerebral infarcts (102-107) and depression (108, 109). These cross-links 
between altered IGF-1 signaling and increased risk of $\mathrm{AD}$ highlight the importance of experimental and metaanalytic evidence, replication studies and a thorough consideration of potential confounders in the association between IGF-1 signaling and Alzheimer's disease.

\section{Conclusion and future perspectives}

Although there are contradictory findings on the association between physical exercise, diet and IGF-1 it can be argued that promoting physical activity and a protein rich diet could be promising interventions that may increase IGF-1 levels, thereby increasing physical fitness and counteracting age-related neurodegeneration and AD. Further research, including experimental, epidemiological and multi-omic approaches (110), is warranted to investigate the prospective value of different biomarker profiles for future dementia risk. Findings can be applied to improve early diagnostics and to increase the efficiency of lifestyle interventions targeting IGF-1 signaling to delay or prevent the development of physical and cognitive decline, in particular for those most vulnerable for AD.

\section{Highlights}

- IGF-1 is associated with cognitive deficits and pathological alterations in the brain that accompany $\mathrm{AD}$

- Decreased IGF-1 levels are a possible moderator of genetic vulnerability to $\mathrm{AD}$

- Increasing physical activity and adherence to a protein rich diet may be useful interventions to increase IGFserum levels, thereby increasing physical fitness and cognitive functioning

Funding: The authors received no financial support for the research, authorship or publication of this manuscript.

Conflict of interests: All authors declare that they have no conflict of interest.

Open Access: This article is distributed under the terms of the Creative Commons Attribution 4.0 International License (http:/ / creativecommons.org/ licenses/by/4.0/), which permits use, duplication, adaptation, distribution and reproduction in any medium or format, as long as you give appropriate credit to the original author(s) and the source, provide a link to the Creative Commons license and indicate if changes were made.

\section{References}

1. Peters R. Ageing and the brain. Postgrad Med J 2006;82:84-8. https:// doi org / 10.1136/pgmj.2005.036665

2. Clegg A, Young J, Iliffe S, et al. Frailty in elderly people. Lancet 2013;381:75262. https: / / doi.org/10.1016/S0140-6736(12)62167-9

3. Keene CD, Montine TJ. Epidemiology, pathology, and pathogenesis of Alzheimer disease. In: Post DW (ed) Up to date. UpToDate, Waltham, MA, 2015;pp 1-18

4. Norat T, Dossus L, Rinaldi S, et al. Diet, serum insulin-like growth factor-I and IGF-binding protein-3 in European women. Eur J Clin Nutr 2007;61:91-8. https: / / doi.org/10.1038/sj.ejcn.1602494

5. Moran S, Chen Y, Ruthie A, Nir Y. Alterations in IGF-I affect elderly: Role of physical activity. Eur Rev Aging Phys Act 2007;4:1-8. https://doi. org/10.1007/s11556-007-0022-1

6. Eliakim A, Brasel JA, Mohan S, et al. Physical fitness, endurance training, and the growth hormone-insulin-like growth factor I system in adolescent females. J Clin Endocrinol Metab 1996;81:3986-92. https://doi.org/10.1210/ jcem.81.11.8923848

7. Arwert LI, Deijen JB, Drent ML. The relation between insulin-like growth factor I levels and cognition in healthy elderly: a meta-analysis. Growth Horm IGF Res 2005;15:416-22. https:/ / doi.org/10.1016/j.ghir.2005.09.001

8. Salvatori R. Growth hormone and IGF-1. Rev Endocr Metab Disord 2004;5:1523. https: / / doi.org/10.1023/B:REMD.0000016121.58762.6d

9. McMahon CD, Chai R, Radley-Crabb HG, et al. Lifelong exercise and locally produced insulin-like growth factor-1 (IGF-1) have a modest influence on reducing age-related muscle wasting in mice. Scand J Med Sci Sports 2014;24:e423-435. https: / / doi.org/10.1111/sms.12200

10. Ashpole NM, Sanders JE, Hodges EL, et al. Growth hormone, insulin-like growth factor-1 and the aging brain. Exp Gerontol 2015;68:76-81. https:/ / doi. org /10.1016/j.exger.2014.10.002

11. Lesniak MA, Hill JM, Kiess W, et al. Receptors for insulin-like growth factors I and II: autoradiographic localization in rat brain and comparison to receptors for insulin. Endocrinology 1988;123:2089-99. https:/ / doi.org/10.1210/endo123-4-2089

12. Duan $\mathrm{C}$, Ren H, Gao S. Insulin-like growth factors (IGFs), IGF receptors, and IGF-binding proteins: Roles in skeletal muscle growth and differentiation. Gen Comp Endocrinol 2010;167:344-351. https://doi.org/10.1016/j. ygcen.2010.04.009

13. Kajantie E, Fall CHD, Seppälä M, et al. Serum insulin-like growth factor (IGF)-I and IGF-binding protein-1 in elderly people: relationships with cardiovascular risk factors, body composition, size at birth, and childhood growth. J Clin Endocrinol Metab 2003;88:1059-65. https://doi.org/10.1210/ jc.2002-021380

14. Mauras N, Martinez V, Rini A, Guevara-Aguirre J. Recombinant human insulin-like growth factor I has significant anabolic effects in adults with growth hormone receptor deficiency: studies on protein, glucose, and lipid metabolism. J Clin Endocrinol Metab 2000;85:3036-42. https://doi. org / 10.1210/jcem.85.9.6772

15. Russell-Aulet $M$, Jaffe CA, Demott-Friberg R, Barkan AL. In vivo semiquantification of hypothalamic growth hormone-releasing hormone (GHRH) output in humans: Evidence for relative GHRH deficiency in aging. J Clin Endocrinol Metab 1999;84:3490-3497. https:// doi.org/10.1210/ jc.84.10.3490

16. Vahl N, Jørgensen JOL, Jurik AG, Christiansen JS. Abdominal adiposity and physical fitness are major determinants of the age associated decline in stimulated GH secretion in healthy adults. J Clin Endocrinol Metab 1996;81:2209-2215. https:// doi.org/10.1210/jc.81.6.2209

17. Clemmons DR. Role of IGF-I in skeletal muscle mass maintenance. Trends Endocrinol Metab 2009;20:349-356. https:/ / doi.org/10.1016/j.tem.2009.04.002

18. Cappola AR, Bandeen-Roche K, Wand GS, et al. Association of IGF-I levels with muscle strength and mobility in older women. J Clin Endocrinol Metab 2001;86:4139-46. https: / / doi.org/10.1210/jcem.86.9.7868

19. Fryburg DA, Barrett EJ, Louard R, al. et. Growth hormone acutely stimulates skeletal muscle but not whole-body protein synthesis in humans. Metabolism 1993;42:1223-7. https: / / doi.org/10.1016/0026-0495(93)90285-V

20. Rudman D, Feller AG, Nagraj HS, et al. Effects of Human Growth Hormone in Men over 60 Years Old. N Engl J Med 1990;323:1-6. https: / / doi.org/10.1056/ NEJM199007053230101

21. Dik MG, Pluijm SM., Jonker C, et al. Insulin-like growth factor I (IGF-I) and cognitive decline in older persons. Neurobiol Aging 2003;24:573-581. https:/ / doi.org/10.1016/S0197-4580(02)00136-7

22. Bikle D, Majumdar S, Laib A, et al . The skeletal structure of insulin-like growth factor I-deficient mice. J Bone Miner Res 2001;16:2320-9. https:/ / doi. org $/ 10.1359 / \mathrm{jbmr} .2001 .16 .12 .2320$

23. Courtland HW, Elis S, Wu Y, et al. Serum IGF-1 affects skeletal acquisition in a temporal and compartment-specific manner. PLoS One 2011;6:1-10. https:/ / doi.org/10.1371/journal.pone.0014762

24. Finkenstedt G, Gasser RW, Höfle G, et al. Effects of growth hormone (GH) replacement on bone metabolism and mineral density in adult onset of $\mathrm{GH}$ deficiency: results of a double-blind placebo-controlled study with open follow-up. Eur J Endocrinol 1997;136:282-9

25. Brill KT, Weltman AL, Gentili A, et al. Single and Combined Effects of Growth Hormone and Testosterone Administration on Measures of Body Composition, Physical Performance, Mood, Sexual Function, Bone Turnover, and Muscle Gene Expression in Healthy Older Men. J Clin Endocrinol Metab 2002;87:5649-5657. https:// doi.org/10.1210/jc.2002-020098

26. Ohlsson C, Mellström D, Carlzon D, et al. Older men with low serum IGF-1 have an increased risk of incident fractures: the MrOS Sweden study. J Bone Miner Res 2011;26:865-72. https:/ / doi.org/10.1002/jbmr.281

27. Adem A, Jossan SS, d'Argy R, et al. Insulin-like growth factor 1 (IGF-1) receptors in the human brain: quantitative autoradiographic localization. Brain Res 1989;503:299-303

28. Bedse G, Di Domenico F, Serviddio G, Cassano T. Aberrant insulin signaling in Alzheimer's disease: Current knowledge. Front Neurosci 2015;9:. https:/ / doi.org/10.3389/ fnins.2015.00204

29. Sonntag WE, Lynch CD, Bennett SA, et al. Alterations in insulin-like growth factor-1 gene and protein expression and type 1 insulin-like growth factor receptors in the brains of ageing rats. Neuroscience 1999;88:269-79 
30. Pañeda C, Arroba AI, Frago LM, et al. Growth hormone-releasing peptide-6 inhibits cerebellar cell death in aged rats. Neuroreport 2003;14:1633-5. https: / / doi.org/10.1097/01.wnr.0000086252.76504.e3

31. O'Sullivan M, Jones DK, Summers PE, et al. Evidence for cortical "disconnection" as a mechanism of age-related cognitive decline. Neurology 2001;57:632-638. https: / / doi.org/10.1212/WNL.57.4.632

32. Bartzokis G. Age-related myelin breakdown: a developmental model of cognitive decline and Alzheimer's disease. Neurobiol Aging 2004;25:5-18. https: / / doi.org/10.1016/j.neurobiolaging.2003.03.001

33. Deijen JB, Arwert LI, Drent ML. The GH/IGF-I Axis and Cognitive Changes across a 4-Year Period in Healthy Adults. ISRN Endocrinol 2011;1-6. https: / / doi.org/10.5402/2011/249421

34. Bellar D, Glickman EL, Juvancic-Heltzel J, Gunstad J. Serum insulin like growth factor- 1 is associated with working memory, executive function and selective attention in a sample of healthy, fit older adults. Neuroscience 2011;178:133-137. https:/ / doi.org/10.1016/j.neuroscience.2010.12.023

35. Al-Delaimy WK, von Muhlen D, Barrett-Connor E. Insulinlike growth factor-1, insulinlike growth factor binding protein-1, and cognitive function in older men and women. J Am Geriatr Soc 2009;57:1441-6. https: / doi. org/10.1111/j.1532-5415.2009.02343.x

36. Maass A, Düzel S, Brigadski T, et al. Relationships of peripheral IGF-1, VEGF and BDNF levels to exercise-related changes in memory, hippocampal perfusion and volumes in older adults. Neuroimage, 2015. https:// doi. org/10.1016/j.neuroimage.2015.10.084

37. Arwert LI, Deijen JB, Müller M, Drent ML. Long-term growth hormone treatment preserves GH-induced memory and mood improvements: A 10-year follow-up study in GH-deficient adult men. Horm Behav 2005;47:343349. https: / / doi.org/10.1016/j.yhbeh.2004.11.015

38. Doi T, Shimada H, Makizako H, et al. Association of insulin-like growth factor-1 with mild cognitive impairment and slow gait speed. Neurobiol Aging 2015;36:942-7. https: / / doi.org/10.1016/j.neurobiolaging.2014.10.035

39. Calvo D, Gunstad J, Miller LA, et al. Higher serum insulin-like growth factor-1 is associated with better cognitive performance in persons with mild cognitive impairment. Psychogeriatrics 2013;13:170-4. https://doi.org/10.1111/ psyg.12023

40. Alvarez A, Cacabelos R, Sanpedro C, et al. Serum TNF-alpha levels are increased and correlate negatively with free IGF-I in Alzheimer disease. Neurobiol Aging 2007;28:533-6. https://doi.org/10.1016/j. neurobiolaging.2006.02.012

41. Hardy J, Selkoe DJ. The amyloid hypothesis of Alzheimer's disease: progress and problems on the road to therapeutics. Science 2002;297:353-6. https: / / doi. org/10.1126/science.1072994

42. Westwood AJ, Beiser A, Decarli C, et al. Insulin-like growth factor-1 and risk of Alzheimer dementia and brain atrophy. Neurology 2014;82:1613-9. https: / / doi.org/10.1212/WNL.0000000000000382

43. Talbot K, Wang H-Y, Kazi H, et al. Demonstrated brain insulin resistance in Alzheimer's disease patients is associated with IGF-1 resistance, IRS-1 dysregulation, and cognitive decline. J Clin Invest 2012;122:1316-1338. https: / / doi.org/10.1172/JCI59903

44. Moloney AM, Griffin RJ, Timmons S, et al. Defects in IGF-1 receptor, insulin receptor and IRS-1/2 in Alzheimer's disease indicate possible resistance to IGF-1 and insulin signalling. Neurobiol Aging 2010;31:224-43. https:/ / doi. org/10.1016/j.neurobiolaging.2008.04.002

45. de la Monte SM. Contributions of brain insulin resistance and deficiency in amyloid-related neurodegeneration in Alzheimer's disease. Drugs 2012;72:4966. https: / / doi.org/10.2165/11597760-000000000-00000

46. Suh Y, Atzmon G, Cho M-O, et al. Functionally significant insulin-like growth factor I receptor mutations in centenarians. Proc Natl Acad Sci U S A 2008;105:3438-42. https: / / doi.org/10.1073/ pnas.0705467105

47. Milman S, Atzmon G, Huffman DM, et al. Low insulin-like growth factor-1 level predicts survival in humans with exceptional longevity. Aging Cell 2014;13:769-771. https: / / doi.org/10.1111/acel.12213

48. Tazearslan C, Huang J, Barzilai N, Suh Y (2011. Impaired IGF1R signaling in cells expressing longevity-associated human IGF1R alleles. Aging Cell 2011;10:551-554. https: / / doi.org/10.1111/j.1474-9726.2011.00697.x

49. Tatar M, Kopelman A, Epstein D, et al. A mutant Drosophila insulin receptor homolog that extends life-span and impairs neuroendocrine function. Science 2001(80- ) 292:107-110. https: / / doi.org/10.1126/ science.1057987

50. Parrella E, Maxim T, Maialetti F, et al. Protein restriction cycles reduce IGF-1 and phosphorylated tau, and improve behavioral performance in an Alzheimer's disease mouse model. Aging Cell 2013;12:257-268. https:// doi. org/10.1111/ acel.12049

51. Ostrowski PP, Barszczyk A, Forstenpointner J, et al. Meta-analysis of serum insulin-like growth factor 1 in Alzheimer's disease. PLoS One 2016;11:1-12. https: / / doi.org/10.1371/journal.pone.0155733

52. Rohn TT. Proteolytic cleavage of apolipoprotein E4 as the keystone for the heightened risk associated with Alzheimer's disease. Int J Mol Sci 2013;14:14908-22. https: / / doi.org/10.3390/ijms140714908

53. Farrer LA. Effects of Age, Sex, and Ethnicity on the Association Between Apolipoprotein E Genotype and Alzheimer Disease. JAMA 1997;278:1349. https: / / doi.org/10.1001/jama.1997.03550160069041

54. Farrer LA, Cupples LA, Haines JL, et al. Effects of age, sex, and ethnicity on the association between apolipoprotein E genotype and Alzheimer disease. A meta-analysis. JAMA 1997;278:1349-56. https://doi.org/10.1001/ jama.1997.03550160069041

55. Liu C-C, Liu C-C, Kanekiyo T, et al. Apolipoprotein E and Alzheimer disease: risk, mechanisms and therapy. Nat Rev Neurol 2013;9:106-18. https://doi. org/10.1038/nrneurol.2012.263

56. Marioni RE, Campbell A, Scotland G, et al. Differential effects of the APOE e4 allele on different domains of cognitive ability across the life-course. Eur J Hum Genet 2015;24:919-923. https:// doi.org/10.1038/ ejhg.2015.210

57. Hori $\mathrm{Y}$, Hashimoto $\mathrm{T}$, Nomoto $\mathrm{H}$, et al. Role of Apolipoprotein $\mathrm{E}$ in B-Amyloidogenesis. J Biol Chem 2015;290:15163-15174. https://doi. org/10.1074/jbc.M114.622209

58. Kumar NT, Liestøl K, Løberg EM, et al. Apolipoprotein E allelotype is associated with neuropathological findings in Alzheimer's disease. Virchows Arch 2015;467:225-35. https: / / doi.org/10.1007/s00428-015-1772-1

59. Galle SA, Van Der Spek A, Drent ML, et al. Revisiting the role of insulinlike growth factor-I receptor stimulating activity and the apolipoprotein E in Alzheimer's disease. Front Aging Neurosci 2019;10:1-9. https: / / doi. org/10.3389/fnagi.2019.00020

60. Liu D, Pan X, Zhang J, et al. APOE4 enhances age-dependent decline in cognitive function by down-regulating an NMDA receptor pathway in EFADTg mice. Mol Neurodegener 2015;10:7. https:/ / doi.org/10.1186/s13024-0150002-2

61. Chen QS, Kagan BL, Hirakura Y, Xie CW. Impairment of hippocampal long-term potentiation by Alzheimer amyloid beta-peptides. J Neurosci Res 2000;60:65-72

62. Le Grevès $M$, Le Grevès $P$, Nyberg F. Age-related effects of IGF-1 on the NMDA-, GH- and IGF-1-receptor mRNA transcripts in the rat hippocampus. Brain Res Bull 2005;65:369-374. https://doi.org/10.1016/j. brainresbull.2005.01.012

63. Wildsmith KR, Holley M, Savage JC, et al. Evidence for impaired amyloid $\beta$ clearance in Alzheimer's disease. Alzheimers Res Ther 2013;5:33. https: / / doi. org/10.1186/alzrt187

64. Gasparini L, Xu H. Potential roles of insulin and IGF-1 in Alzheimer's disease. Trends Neurosci 2003;26:404-406. https: / / doi.org/10.1016/S01662236(03)00163-2

65. Keeney JT-R, Ibrahimi S, Zhao L. Human ApoE Isoforms Differentially Modulate Glucose and Amyloid Metabolic Pathways in Female Brain Evidence of the Mechanism of Neuroprotection by ApoE2 and Implications for Alzheimer's Disease Prevention and Early Intervention. J Alzheimer's Dis 2015;48:411-424. https: / / doi.org/10.3233/JAD-150348

66. Simpson JE, Ince PG, Shaw PJ, et al. Microarray analysis of the astrocyte transcriptome in the aging brain: Relationship to Alzheimer's pathology and APOE genotype. Neurobiol Aging 2011;32:1795-1807. https:// doi org/10.1016/j.neurobiolaging.2011.04.013

67. Huang WJ, Zhang X, Chen WW. Role of oxidative stress in Alzheimer's disease (review). Biomed Reports 2016;4:519-522. https://doi.org/10.3892/ br.2016.630

68. Craft S, Asthana S, Schellenberg G, et al. Insulin effects on glucose metabolism, memory, and plasma amyloid precursor protein in Alzheimer's disease differ according to apolipoprotein-E genotype. Ann N Y Acad Sci 2000;903:222-228. https:/ / doi.org/10.1111/j.1749-6632.2000.tb06371.x

69. Reger MA, Watson GS, Frey WH, et al. Effects of intranasal insulin on cognition in memory-impaired older adults: Modulation by APOE genotype. Neurobiol Aging 2006;27:451-458. https:// doi.org/10.1016/j. neurobiolaging.2005.03.016

70. van der Lee SJ, Wolters FJ, Ikram MK, et al. The effect of APOE and other common genetic variants on the onset of Alzheimer's disease and dementia: a community-based cohort study. Lancet Neurol 2018;17:434-444. https:// doi. org/10.1016/S1474-4422(18)30053-X

71. Deelen J, Beekman M, Uh HW, et al. Genome-wide association study identifies a single major locus contributing to survival into old age; the APOE locus revisited. Aging Cell 2011;10:686-698. https:// doi.org/10.1111/j.14749726.2011.00705.x

72. Yu J-L, Ma L, Ma L, Tao Y-Z. [Voluntary wheel running enhances cell proliferation and expression levels of BDNF, IGF1 and WNT4 in dentate gyrus of adult mice]. Sheng Li Xue Bao 2014;66:559-68

73. Ardawi M-SM, Rouzi AA, Qari MH. Physical activity in relation to serum sclerostin, insulin-like growth factor-1, and bone turnover markers in healthy premenopausal women: a cross-sectional and a longitudinal study. J Clin Endocrinol Metab 2012;97:3691-9. https: / / doi.org/10.1210/jc.2011-3361

74. Koziris LP, Hickson RC, Chatterton RT, et al. Serum levels of total and free IGF-I and IGFBP-3 are increased and maintained in long-term training. J Appl Physiol 1999;86:1436-42

75. Amir R, Ben-Sira D, Sagiv M. Igf-I and fgf-2 responses to wingate anaerobic test in older men. J Sports Sci Med 2007;6:227-32

76. Stein AM, Silva TMV, Coelho FG de M, et al. Physical exercise, IGF-1 and cognition A systematic review of experimental studies in the elderly. Dement Neuropsychol 2018;12:114-122. https: / / doi.org/10.1590/198057642018dn12-020003

77. Rarick KR, Pikosky MA, Grediagin A, et al. Energy flux, more so than energy balance, protein intake, or fitness level, influences insulin-like growth factor-I 
system responses during 7 days of increased physical activity. J Appl Physiol 2007;103:1613-21. https:/ / doi.org/10.1152/japplphysiol.00179.2007

78. Nindl BC, Headley SA, Tuckow AP, et al. IGF-I system responses during 12 weeks of resistance training in end-stage renal disease patients. Growth Horm IGF Res 220414:245-50. https: / / doi.org/10.1016/j.ghir.2004.01.007

79. Schmitz KH, Ahmed RL, Yee D. Effects of a 9-month strength training intervention on insulin, insulin-like growth factor (IGF)-I, IGF-binding protein (IGFBP)-1, and IGFBP-3 in 30-50-year-old women. Cancer Epidemiol Biomarkers Prev 2002;11:1597-604

80. Ntanasis-Stathopoulos J, Tzanninis JG, Philippou A, Koutsilieris M. Epigenetic regulation on gene expression induced by physical exercise. J Musculoskelet Neuronal Interact 2013;13:133-46

81. Jablonka E, Lamb MJ. The inheritance of acquired epigenetic variations. Int J Epidemiol 2915;44:1094-103. https:/ / doi.org/10.1093/ije/dyv020

82. Schuit AJ, Feskens EJM, Launer LJ, Kromhout D. Physical activity and cognitive decline, the role of the apolipoprotein e4 allele. Med Sci Sports Exerc 2001;33:772-777

83. Rovio S, Kåreholt I, Helkala E-L, et al. Leisure-time physical activity at midlife and the risk of dementia and Alzheimer's disease. Lancet Neurol 2005;4:705711. https: / / doi.org/10.1016/S1474-4422(05)70198-8

84. Kivipelto M, Rovio S, Ngandu T, et al. Apolipoprotein E epsilon4 magnifies lifestyle risks for dementia: a population-based study. J Cell Mol Med 2008;12:2762-71. https: / / doi.org/10.1111/j.1582-4934.2008.00296.x

85. Deeny SP, Poeppel D, Zimmerman JB, et al. Exercise, APOE, and working memory: MEG and behavioral evidence for benefit of exercise in epsilon4 carriers. Biol Psychol 2008;78:179-187. https://doi.org/10.1016/j. biopsycho.2008.02.007

86. Head D, Bugg JM, Goate AM, et al. Exercise engagement as a moderator of the effects of APOE genotype on amyloid deposition. Arch Neurol 2012;69:636 https: / / doi.org/10.1001/archneurol.2011.845

87. Smith JC, Nielson $\mathrm{K}$ a., Woodard JL, et al. Physical activity reduces hippocampal atrophy in elders at genetic risk for Alzheimer's disease. Front Aging Neurosci 2014;6:1-7. https: / / doi.org/10.3389/fnagi.2014.00061

88. Smith JC, Nielson KA, Woodard JL, et al. Interactive effects of physical activity and APOE-e4 on BOLD semantic memory activation in healthy elders. Neuroimage 2011;54:635-644. https://doi.org/10.1016/j. neuroimage.2010.07.070

89. Podewils LJ, Guallar E, Kuller LH, et al. Physical activity, APOE genotype, and dementia risk: Findings from the Cardiovascular Health Cognition Study. Am J Epidemiol 2005;161:639-651. https: / / doi.org/10.1093/aje/kwi092

90. Fenesi B, Fang H, Kovacevic A, et al. Physical exercise moderates the relationship of apolipoprotein E (APOE) genotype and dementia risk: a population-based study. J Alzheimer's Dis 2017;56:297-303. https:/ / doi. org/10.3233/JAD-160424

91. Lautenschlager NT, Cox KL, Flicker L, et al. Effect of physical activity on cognitive function in older adults at risk for Alzheimer disease: A randomized trial. JAMA - J Am Med Assoc 2008;300:1027-1037. https: / doi.org/10.1001/ jama.300.9.1027

92. Luck T, Riedel-Heller SG, Luppa M, et al. Apolipoprotein E epsilon 4 genotype and a physically active lifestyle in late life: analysis of geneenvironment interaction for the risk of dementia and Alzheimer's disease dementia. Psychol Med 2014;44:1319-29. https://doi.org/10.1017/ S0033291713001918

93. Buchman AS, Boyle PA, Wilson RS, et al. Apolipoprotein E e4 allele is associated with more rapid motor decline in older persons. Alzheimer Dis Assoc Disord 2009;23:63-9

94. Allen NE, Appleby PN, Davey GK, et al. The associations of diet with serum insulin-like growth factor I and its main binding proteins in 292 women meat-eaters, vegetarians, and vegans. Cancer Epidemiol Biomarkers Prev 2002;11:1441-8
95. Fontana L, Weiss EP, Villareal DT, et al. Long-term effects of calorie or protein restriction on serum IGF-1 and IGFBP-3 concentration in humans. Aging Cell 2008;7:681-7

96. Fontana L, Villareal DT, Das SK, et al. Effects of 2-year calorie restriction on circulating levels of IGF-1, IGF-binding proteins and cortisol in nonobese men and women: a randomized clinical trial. Aging Cell 2016;15:22-7. https: / doi. org/10.1111/acel.12400

97. Smith WJ, Underwood LE, Clemmons DR. Effects of caloric or protein restriction on insulin-like growth factor-I (IGF-I) and IGF-binding proteins in children and adults. J Clin Endocrinol Metab 1995;80:443-9. https: / / doi org/10.1210/jcem.80.2.7531712

98. Smith AT, Clemmons DR, Underwood LE, et al. The effect of exercise on plasma somatomedin-C/insulinlike growth factor I concentrations. Metabolism 1987;36:533-537. https:/ / doi.org/10.1016/0026-0495(87)90162-4

99. Durazzo TC, Mattsson N, Weiner MW. Smoking and increased Alzheimer's disease risk: A review of potential mechanisms, 2014. https://doi. org/10.1016/j.jalz.2014.04.009

100. Tong M, Yu R, Deochand C, De La Monte SM. Differential contributions of alcohol and the nicotine-derived nitrosamine ketone (NNK) to insulin and insulin-like growth factor resistance in the adolescent rat brain. Alcohol Alcohol 2014;50:670-679. https: / / doi.org/10.1093/alcalc/agv101

101. De La Monte SM, Tong M, Cohen AC, et al. Insulin and insulin-like growth factor resistance in alcoholic neurodegeneration. Alcohol Clin Exp Res 2008;32:1630-1644. https: / / doi.org/10.1111/j.1530-0277.2008.00731.x

102. Li X, Song D, Leng SX. Link between type 2 diabetes and Alzheimer's disease: From epidemiology to mechanism and treatment. Clin Interv Aging 2015;10:549-560. https: / / doi.org/10.2147/CIA.S74042

103. Talbot $\mathrm{K}$, Wang $\mathrm{H}$, Kazi $\mathrm{H}$, et al. Demonstrated brain insulin resistance in Alzheimer's disease patients is associated with IGF-1 resistance, IRS-1 dysregulation, and cognitive decline. J Clin Invest 2012;122:1316-1338. https: / / doi.org/10.1172/JCI59903

104. Steen E, Terry BM, Rivera EJ, et al. Impaired insulin and insulin-like growth factor expression and signaling mechanisms in Alzheimer's disease--is this type 3 diabetes? J Alzheimers Dis 2005;7:63-80. https:/ / doi.org/10.3233/JAD2005-7107

105. Vagelatos NT, Eslick GD. Type 2 diabetes as a risk factor for Alzheimer's disease: The confounders, interactions, and neuropathology associated with this relationship. Epidemiol Rev 2013;35:152-160. https://doi.org/10.1093/ epirev/mxs012

106. Spielman LJ, Little JP, Klegeris A. Inflammation and insulin/IGF-1 resistance as the possible link between obesity and neurodegeneration. J. Neuroimmunol. 2014;273:8-21

107. Rochoy M, Rivas V, Chazard E, et al. Factors Associated with Alzheimer's Disease: An Overview of Reviews. J Prev Alzheimer's Dis 2019;6:121-134. https:/ / doi.org/10.14283/jpad.2019.7

108. Paslakis G, Blum WF, Deuschle M. Intranasal insulin-like growth factor I (IGFI) as a plausible future treatment of depression. Med Hypotheses 2012;79:222225. https: / / doi.org/10.1016/j.mehy.2012.04.045

109. Mueller PL, Pritchett CE, Wiechman TN, et al. Antidepressant-like effects of insulin and IGF-1 are mediated by IGF-1 receptors in the brain. Brain Res Bull 2018;143:27-35. https:/ / doi.org/10.1016/j.brainresbull.2018.09.017

110. Bateman RJ, Blennow K, Doody R, et al. Plasma Biomarkers of AD Emerging as Essential Tools for Drug Development: An EU/US CTAD Task Force Report. J Prev Alzheimer's Dis 2019;6:169-173. https://doi.org/10.14283/ jpad.2019.21 